\title{
Biocontrol of Escherichia coli 0157:H7 in ready-to-eat salad using a lytic bacteriophage
}

\author{
GIZEM CUFAOGLU, BAHAR ONARAN* NAIM DENIZ AYAZ, \\ MUAMMER GONCUOGLU*, FATMA SEDA ORMANCI*

\begin{abstract}
Department of Food Hygiene and Technology, Faculty of Veterinary Medicine, Kirikkale University, 71450 Yahsihan, Kirikkale, Turkey

*Department of Food Hygiene and Technology, Faculty of Veterinary Medicine, Ankara University, 06110 Diskapi, Ankara, Turkey
\end{abstract}

\section{Cufaoglu G., Onaran B., Ayaz N. D., Goncuoglu M., Ormanci F. S. Biocontrol of Escherichia coli 0157:H7 in ready-to-eat salad using a lytic bacteriophage}

\section{Summary}

E. coli O157:H7 is a life threatening foodborne pathogen associated with thousands of infections. Controlling such bacterial pathogens in raw and ready-to-eat foods has gained urgency with each passing day. The use of specific virulent bacteriophages as a biocontrol agent on minimally processed foods is an effective, natural and non-destructive treatment. This study was aimed at determining the efficiency of a lytic bacteriophage against E. coli O157:H7 in ready-to-eat salads. For this purpose, E. coli O157:H7 NCTC 12900 (EC00) and nalidixic acid resistant E. coli 0157:H7 ATCC 43895 (NA-EC95) were used as the model bacterium in decontamination trials of mayonnaise based ready-to-eat salads which are consumed without any heating process and include beans, carrots, potatoes, pickled cucumbers and salami. A previously described phage M8AEC16 which was classified in Myoviridae family was used as the biocontrol agent. The highest reductions were observed at $22^{\circ} \mathrm{C}$ storage conditions. Reductions reaching up to $2.7 \mathrm{log}$ cfu/g of viable E. coli 0157:H7 counts were observed in the beginning of the storage period. The findings of the study showed that phage M8AEC16 can be used as a biocontrol agent in the decontamination of $\mathrm{E}$. coli $\mathrm{O} 157: \mathrm{H} 7$ in such mayonnaise based ready-to-eat salads.

Keywords: E. coli O157:H7, bacteriophage, biocontrol, ready-to-eat salad

Shiga-toxin producing Escherichia coli O157:H7 (STEC) is a significant foodborne pathogen which is responsible for acute gastroenteritis and further serious complications. Especially children under five and elders are at risk of developing haemolytic uremic syndrome (HUS) that can result with permanent kidney failure. Unfortunately, antibiotic treatment enhances the risk of developing HUS particularly in children as it may cause Shiga toxin release (13).

Outbreaks caused by E. coli $\mathrm{O} 157: \mathrm{H} 7$ originated from ready-to-eat (RTE) salads have increased recently in the world (http://www.cdc.gov/foodsafety/outbreaks/ multistate-outbreaks/outbreaks-list.html). In the last decade, E. coli O157:H7 outbreaks associated with the consumption of fresh spinach, romaine lettuce, inshell hazelnuts, alfalfa sprouts, watercress have been reported (http://www.cdc.gov/ecoli/outbreaks.html) (8). Moreover, RTE salads with meat products are also a potential risk for infections and there have been many outbreaks associated with animal originating food contaminated with E. coli O157:H7 (https://www.cdc.gov/ ecoli/2013/o157h7-11-13/index.html) (10).
Mayonnaise based salads which were used in this study are ready-to-eat (RTE) appetizers that are called "İtalyan salatası (Italian salad)" in Turkish cuisine. The salad commonly includes beans, carrots, potatoes, pickled cucumbers and salami. The ingredients and mayonnaise are found mixed very well in these salads. They are generally sold unpackaged and daily consumed in sandwiches or as deli food. Like other RTE salads, these salads also can be contaminated at any of the stages of preparation and are consumed without any heating process.

Bacteriophages, the viruses which kill bacteria, are the most numerous organisms on earth with a population of $10^{30-32}$ and can exist in all kinds of environments where their hosts live (7). The emergence of antibiotic resistant bacteria leads scientists to consider bacteriophages as an effective, safe and appropriate biocontrol agent and an alternative option for antibiotics and chemicals. Among two types of phages (lytic and lysogenic), lytic phages that can only multiply in bacteria and kill the cell by lysis are generally preferred from a food safety perspective (11). 
The aim of this study was to investigate the decontamination efficiency of a lytic bacteriophage, M8AEC16, on nalidixic acid resistant and sensitive $E$. coli $\mathrm{O} 157: \mathrm{H} 7$ strains in a ready-to-eat salad model.

\section{Material and methods}

Bacterial cultures. Nalidixic acid resistant E. coli O157:H7 ATCC 43895 (NA-EC95) and NCTC 12900 (EC00) were used as the contaminants. To increase the selectivity, ATCC 43895 was made resistant to nalidixic acid (100 $\mu \mathrm{g} / \mathrm{mL}$ ) by serial passages of increasing concentrations of nalidixic acid $(25,50,100 \mu \mathrm{g} / \mathrm{mL})$ in Tryptone Soya Broth (TSB, Oxoid CM0129, Hampshire, UK). Fifty ml of broth cultures were centrifuged at $5000 \times \mathrm{g}$ for $7 \mathrm{~min}$ and pellets were resuspended in physiological saline solution (PS, $0.9 \%$ $\mathrm{NaCl}$ ) at $0.5 \mathrm{McF}$ arland (approx. $1.5 \times 10^{8}$ cells $/ \mathrm{ml}, 0.125 \mathrm{OD}$ at $550 \mathrm{~nm}$ ) (Biosan McFarland Densitometer, Riga, Latvia). Next, tenfold dilutions of the suspensions were prepared in PS for the inoculation of $10 \mathrm{~g}$ of Italian salads in sterile sample containers.

Bacteriophage. The phage M8AEC16 was isolated from a local slaughterhouse's wastewater efflux in our previous study (3) and was classified in the Myoviridae family by Transmission Electron Microscopy (TEM). The effect of M8AEC16 on E. coli O157:H7 was performed in broth and isolation of the phage was done with soft-agar overlay plate method as Carlson (1) described.

Phage preparation. M8AEC16 was enriched in overnight cultures of NA-EC95 and EC00 in TSB medium at $37^{\circ} \mathrm{C}$. After $18 \mathrm{~h}$ incubation, chloroform was added, centrifuged (3000 g, $15 \mathrm{~min}$ ) and supernatants filtered through a $0.20 \mu \mathrm{m}$ syringe filter. Before using in bacterial trials, phage titer was determined by soft agar overlay technique using both of the host strains (1).

Food model. Packaged mayonnaise based RTE Italian salads which include beans, carrots, potatoes, pickled cucumbers and salami were purchased at a local supermarket in Ankara, Turkey. The salads were analyzed for the absence of $E$. coli $\mathrm{O} 157$ by the immunomagnetic separation (IMS) based cultivation method (6). The salads were aseptically and carefully divided into $10 \mathrm{~g}$ aliquots in sterile sample containers each containing the same ingredients.

Experimental design of Italian salad decontamination with M8AEC16. For each host strain, a phage group and a control group was formed and initial bacteriophage count was determined $9.3 \log \mathrm{pfu} / \mathrm{g}$. For the phage groups, sterile sample containers were decontaminated with two different phage concentration levels thus two different multiplicities of infections (MoIs) were achieved. While NA-EC95 phage group was contaminated with $2.3 \mathrm{log}$ and $4.3 \log \mathrm{cfu} / \mathrm{g}$ bacteria, EC00 phage group was contaminated with $3.9 \log$ and $5.9 \log \mathrm{cfu} / \mathrm{g}$ (Tab. 1). After phage groups was $9.3 \log \mathrm{pfu} / \mathrm{g}$ inoculation of the bacteria and the phage (for the phage groups only) salads were carefully mixed. To demonstrate the real storage conditions of RTE Italian salads, samples were incubated at their related temperatures $\left(4^{\circ} \mathrm{C}, 10^{\circ} \mathrm{C}\right.$ and $22^{\circ} \mathrm{C}$ ). After incubation, enumerations were carried out at 0 , $0.5,1,3$, and 5 hours.

Enumeration of $\boldsymbol{E}$. coli $\mathrm{O} 157: \mathrm{H7}$ strains. At the end of the incubation periods, $\mathrm{pH}$ measurements were performed and $90 \mathrm{ml}$ of peptone water was added to each $10 \mathrm{~g}$ salads. Next, mixtures were thoroughly mixed again. Tenfold dilutions were prepared in peptone water and proper dilutions were plated on MUG-SMAC (SMAC supplemented with 4 -methylumbelliferyl- $\beta$-D-glucuronide), NA-MUG-SMAC (SMAC supplemented with $25 \mu \mathrm{g} / \mathrm{mL}$ of nalidixic acid and 4-methylumbelliferyl- $\beta$-D-glucuronide) and CHROMagar O157. Specific colonies which were positive with the latex test (Oxoid, DR0620) were counted and calculations were done.

Statistical analyses. Two independent replicate experiments were performed for every bacterial contamination level of RTE Italian salads. General Linear Models with repeated measures design were used to investigate the differences in $E$. coli $\mathrm{O} 157: \mathrm{H} 7$ reductions over time and the interactions between time (0., 0.5., 1., 3., and 5. hours) and MoI $(3.4,5.0,5.4$ and $7.0 \log [\mathrm{pfu} / \mathrm{cfu}])$ or temperature groups $\left(4^{\circ} \mathrm{C}, 10^{\circ} \mathrm{C}\right.$ and $\left.22^{\circ} \mathrm{C}\right)$. For the determination of statistical significance of the effect of time and temperature in each of the achieved MoIs, independent two-way ANOVA analyses were used while the effect of varying MoIs were analyzed by a three-way factorial design. Limit of detection was taken as $2.0 \log \left(1.0 \times 10^{2} \mathrm{cfu} / \mathrm{g}\right)$ for statistical analyses. For all comparisons, differences were considered with a minimum of 0.05 significance level. All statistical analyses were performed using SPSS ${ }^{\circledR} 14.1$ for Windows.

\section{Results and discussion}

In this study, previously isolated phage M8AEC16 was used for the biocontrol of two different $E$. coli O157:H7 strains (ATCC 43895 and NCTC 12900) in RTE Italian salads. M8AEC16 is a highly effective phage against various typical sorbitol-fermentation negative $E$. coli $\mathrm{O} 157: \mathrm{H} 7+/ \mathrm{H} 7$ - isolates with a high

Tab. 1. Reduction of the colony counts of $E$. coli $0157: H 7$ in mayonnaise based RTE Italian salad experimentally contaminated with bacteria and bacteriophages at different levels

\begin{tabular}{|c|c|c|c|c|c|c|c|}
\hline \multirow{2}{*}{$\begin{array}{l}\text { Initial Mol } \\
\text { (log [pfu/cfu]) }\end{array}$} & \multirow{2}{*}{$\begin{array}{l}\text { Initial bacterial } \\
\text { count }^{* *}(\log \mathrm{cfu} / \mathrm{g})\end{array}$} & \multirow{2}{*}{ Test strain } & \multirow{2}{*}{$\begin{array}{c}\text { Storage } \\
\text { temperature }\left({ }^{\circ} \mathrm{C}\right)\end{array}$} & \multicolumn{4}{|c|}{ Mean reduction (log cfu/g) } \\
\hline & & & & $0.5 \mathrm{~h}$ & $1 \mathrm{~h}$ & $3 \mathrm{~h}$ & $5 \mathrm{~h}$ \\
\hline 7.0 & 2.3 & NA-EC43895 & 4 & * & * & 0.56 & 1.23 \\
\hline 7.0 & 2.3 & NA-EC43895 & 10 & * & * & 0.91 & 0.38 \\
\hline 7.0 & 2.3 & NA-EC43895 & 22 & * & * & 1.14 & 1.05 \\
\hline 5.4 & 3.9 & EC12900 & 4 & 0.90 & 0.75 & 0.65 & 0.52 \\
\hline 5.4 & 3.9 & EC12900 & 22 & 1.05 & 2.02 & 1.77 & 1.99 \\
\hline 5.0 & 4.3 & NA-EC43895 & 4 & 0.60 & 0.60 & 1.40 & 1.38 \\
\hline 5.0 & 4.3 & NA-EC43895 & 10 & 0.52 & 0.70 & 1.45 & 2.06 \\
\hline 5.0 & 4.3 & NA-EC43895 & 22 & 1.60 & 1.57 & 1.89 & 2.70 \\
\hline 3.4 & 5.9 & EC12900 & 4 & 0.30 & 0.60 & 0.84 & 0.81 \\
\hline 3.4 & 5.9 & EC12900 & 22 & 0.98 & 2.17 & 1.70 & 1.73 \\
\hline
\end{tabular}

Explanations: * under the detection limit of $2.0 \mathrm{log} \mathrm{cfu} / \mathrm{g} ; * *$ initial bacteriophage counts for all 
efficiency of plating (EoP), including NA-EC95 and EC00 (7). Taking into account that if phage host range is too limited it may be inefficient for biocontrol, our phage appears to be quite suitable for this purpose (5).

Considering both strains, the lowest reduction level $(0.3 \log \mathrm{cfu} / \mathrm{g})$ was recorded for EC00 in the first $0.5 \mathrm{~h}$ of refrigerated temperature $\left(4^{\circ} \mathrm{C}\right)$ at $3.4 \log$ initial MoI. On the other hand, the highest reduction $(2.7 \log \mathrm{cfu} / \mathrm{g})$ was achieved for EC95 in $5 \mathrm{~h}$ incubation at room temperature $\left(22^{\circ} \mathrm{C}\right)$ at $5.0 \log$ initial MoI. Although E. coli O157:H7 counts increased in control samples during the room temperature storage, this increment was not seen at $4^{\circ} \mathrm{C}$ incubation (data not shown). In all phage groups, lowest reductions were observed at refrigerated temperature. This may indicate that at $4{ }^{\circ} \mathrm{C}$ phages were incapable of lyse $E$. coli $\mathrm{O} 157: \mathrm{H} 7$ due to the lack of bacterial growth $(5,9)$. Subsequently, at room temperature which the bacteria can thrive easily, the phage showed efficacy with high reductions for both strains.

In recent years, the use of bacteriophages as biocontrol agents has come up again due to the development of multiple antibiotic resistant bacteria (http:// www.cdc.gov/drugresistance/pdf/ar-threats-2013-508. pdf). Therefore, in this current study lytic activity of M8AEC16 over two strains, nalidixic acid resistance E. coli O57:H7 ATCC 43895 (NA-EC95) and nonresistant E. coli O57:H7 NCTC 12900 (EC00) were compared. No significant difference on phage efficacy was seen between NA-EC95 and EC00 at $4{ }^{\circ} \mathrm{C}$ despite of the different initial decontamination levels. Nevertheless, at room temperature nalidixic acid resistant $E$. coli strain was effected more than EC00. To make a certain judgement for the relation between antibiotic resistance and bacteriophage resistivity, more detailed studies are necessary.

In the phage group of NA-EC95, when the initial MoI was $7.0 \mathrm{log}$, bacterial counts were not observed in the first $0.5 \mathrm{~h}$ and $1 \mathrm{~h}$, while in the control group bacterial counts were varied between 2.3-4.3 log cfu/g. Considering the minimal infective dose of $E$. coli O157:H7 is generally lower than $10^{2} \mathrm{cfu} / \mathrm{g}(2)$, phage application may be an effective tool to reduce bacterial count under the detection limit in such RTE foods.

Previous studies stated that when initial phage concentration was higher at the time of application, reduction of the bacteria became greater $(3-5,12)$. In this study, although the highest reductions were observed between 5.0 and $5.4 \log$ initial MoIs, there is no significant effect of different MoI values (log 3.4-7.0) on phage efficacy and reduction. Therefore, in this study when marginal affect is taken into consideration for the usage ability of bacteriophages as a biocontrol agent, it can be concluded that there is no need to use more than $5.0 \log$ MoI considering economic issues.

$\mathrm{pH}$ value of the product was measured at 5.6 in the beginning of the incubation periods and no significant changes were observed at any related temperatures (data not shown).
Guenther et al (4) implied that the efficacy of the phage strongly depended on the food matrix and the type of food. To the best of our knowledge this is the first study on salads that harbor such various vegetables, mayonnaise and meat at the same time. We believe that semi-solid consistency of the Italian salad allowed the phages reach to the whole area and to be easily absorbed. However, there is limited data on the interaction of phages and food matrix.

By bacteriophage application in a semi-solid complex food matrix as mayonnaise based RTE Italian salad, $2.7 \mathrm{log} \mathrm{cfu} / \mathrm{g}$ reduction of $E$. coli $\mathrm{O} 157: \mathrm{H} 7$ ATCC 43895 was observed. In this manner, M8AEC16 can be considered as an efficient biocontrol agent of $E$. coli $\mathrm{O} 157: \mathrm{H} 7$ on RTE Italian salads. The highest reductions were observed at incubation temperature that supports bacterial growth $\left(22^{\circ} \mathrm{C}\right)$. When considering cost-effectiveness and efficiency, it was determined that $5.0 \mathrm{log} \mathrm{MoI}$ is affective for bacteriophage application. The effect of antibiotic resistance development on lytic activity of bacteriophages should be investigated in a detailed manner in further studies.

\section{References}

1. Carlson K.: Working with bacteriophages: Common techniques and methodological approaches, [in:] Kutter E., Sulakvelidze A. (ed.): Bacteriophages, Biology and Applications. CRC Press, Florida 2005, p. 437-490.

2. Erol I. (ed.): Gida hijyeni ve mikrobiyolojisi. Pozitif Matbaacılık, Ankara, Turkey 2007, p. 84.

3. Gencay Y. E., Ayaz N. D., Copuroglu G., Erol I.: Biocontrol of Shiga toxigenic Escherichia coli O157:H7 in Turkish raw meatball by bacteriophage. J. Food Saf. 2016, 36, 120-131

4. Guenther S., Huwyler D., Richard S., Loessner M. J.: Virulent bacteriophage for efficient biocontrol of Listeria monocytogenes in ready-to-eat foods. Appl. Environ. Microbiol. 2009, 75, 93-100.

5.Hudson J. A., Billington C., Cornelius A. J., Wilson T., On S. L. W., Premaratne A., King N. J.: Use of a bacteriophage to inactivate Escherichia coli O157:H7 on beef. Food Microbiol. 2013, 36, 14-21.

6. ISO 16654:2001(E): Microbiology of food and animal feeding stuffs: Horizontal method for the detection of Escherichia coli O157, 2001.

7. Kim E. J., Lee H., Lee J. H., Ryu S., ParkJ. H.: Morphological features and lipopolysaccharide attachment of coliphages specific to Escherichia coli O157:H7 and to a broad range of E. coli hosts. Appl. Biol. Chem. 2016, 59, 109-116.

8.Launders N., Byrne L., Adams N., Glen K., Jenkins C., Tubin-Delic D. Locking M., Williams C., Morgan D.: Outbreak of Shiga toxin-producing E. coli $\mathrm{O} 157$ associated with consumption of watercress, United Kingdom, August to September 2013. Euro Surveill. 2013, 18, 1-5.

9. O'Flynn G., Ross R. P., Fitzgerald G. F., Coffey A.: Evaluation of a cocktail of three bacteriophages for biocontrol of Escherichia coli O157:H7. Appl. Environ. Microbiol. 2004, 70, 3417-3424.

10. Sartz L., De Jong B., Hjertqvist M., Plym-Forshell L., Alsterlund R., Löfdahl S., Osterman B., Stahl A., Eriksson E., Hansson H. B., Karpman D.: An outbreak of Escherichia coli O157:H7 infection in southern Sweden associated with consumption of fermented sausage; aspects of sausage production that increase the risk of contamination. Epidemiol. Infect. 2008, 136, 370-380.

11. Sulakvelidze A., Alavidze Z., Morris J. G. Jr.: Bacteriophage Therapy. Antimicrob. Agents Chemother. 2001, 45, 649-659.

12. Tomat D., Migliore L., Aquili V., Quiberoni A., Balagué C.: Phage biocontrol of enteropathogenic and shiga toxin-producing Escherichia coli in meat products. Front. Cell. Infect. Microbiol. 2013, 3, 1-10.

13. Wong C. S., Jelacic S., Habeeb R. L., Watkins S. L., Tarr P. I.: The risk of the hemolytic-uremic syndrome after antibiotic treatment of Escherichia coli O157:H7 infections. N. Engl. J. Med. 2000, 342, 1930-1936.

Corresponding author: Naim Deniz AYAZ, Assoc. Prof. DVM, Faculty of Veterinary Medicine, Department of Food Hygiene and Technology, 71450 Yahsihan, Kirikkale, Turkey; e-mail: naimdenizayaz@kku.edu.tr 